\title{
THE PETROLOGY AND GEOCHEMISTRY OF THE SWARTRUGGENS AND STAR KIMBERLITE DYKE SWARMS, SOUTH AFRICA
}

\author{
Nancy Coe, Anton le Roex and John Gurney \\ Department of Geological Sciences, University of Cape Town, South Africa
}

\section{INTRODUCTION}

The Swartruggens and Star kimberlites are two Group II, diamondiferous, hypabyssal kimberlite dyke swarms, situated in the Northern Province and the Free State respectively, South Africa. Representative samples from all dykes from each locality have been analysed for their major and trace element contents.

Primary kimberlite magma chemistry is subjected to considerable modification due to the incorporation of both mantle and crustal material during ascent to the surface, crystal fractionation, and post-emplacement alteration by deuteric fluids. This study aims to constrain the effects of these processes, and thus to identify least-modified, close-to-primary, parental magma compositions, with the view to understanding the source region characteristics of, and the petrogenetic processes giving rise to, these kimberlites.

\section{ANALYTICAL}

The samples were crushed to approximately $1 \mathrm{~cm}$ in size using a jaw crusher. Fragments were then picked by hand in order to avoid, as far as possible, all xenolithic material, veins, and weathered surfaces, before being powdered in a carbon-steel Sieb swing mill. Major and some trace element analyses were carried out by X-ray fluorescence (XRF) using a low dilution fusion technique and a Philips X'Unique wavelength spectrometer. Errors and detection limits are similar to those reported by le Roex et al. (1981). The majority of trace element analyses were determined by solution ICP-MS, using a Perkin Elmer ELAN 6000 ICP-MS with the method, accuracy and detection limits described in le Roex et al. (2001). $\mathrm{CO}_{2}$ analyses were carried out using a karbonat-bombe with the method of Birch (1981), with approximately 5\% relative precision.

\section{PETROGRAPHY}

Petrographically the kimberlites at both localities are similar to other South African micaceous kimberlites, containing rounded, anhedral, macrocrystic olivine (variably altered to serpentine and calcite) and kinkbanded macrocrystic phlogopite in a fine-grained groundmass of phlogopite, olivine, and carbonate with or without diopside, melilite, and minor apatite, perovskite and $\mathrm{Fe}-\mathrm{Ti}$ oxides. Occasional rounded eclogitic garnets are present in some samples. The Muil (barren) dyke of the Swartruggens kimberlite is petrographically different from the others in that it consists of olivine macrocrysts in a groundmass of phlogopite, diopside and sanidine. Sanidine is not normally present in a kimberlite and the Muil dyke has previously been described as lamprophyric (Skinner and Scott, 1979).

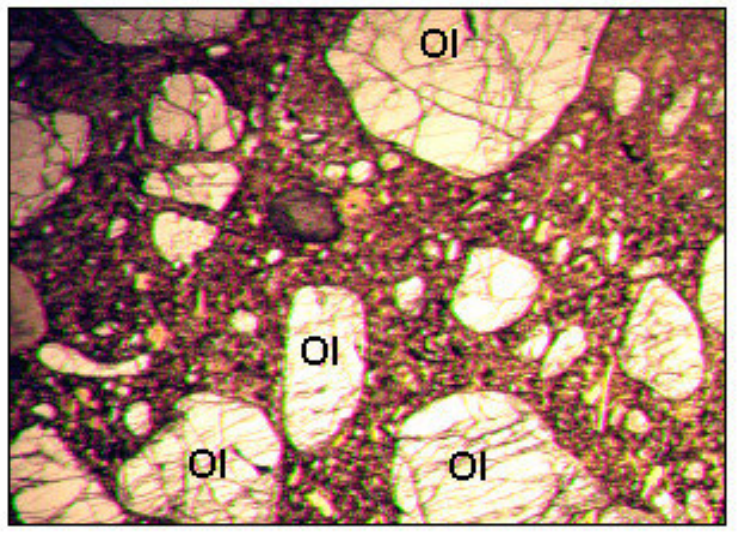

Figure 1: Photomicrograph showing typical appearance of rounded olivine macrocrysts in a macrocrystic section of the East Star Dyke, Star. Ol = olivine macrocryst. $\mathrm{FOV}=5 \mathrm{~mm}$

\section{GEOCHEMISTRY}

Major and trace element variations are considerable at each locality. The Swartruggens kimberlite has $\mathrm{MgO}=$ $10-25 \mathrm{wt} \%, \mathrm{SiO}_{2}=25-47 \mathrm{wt} \%$ and $\mathrm{K}_{2} \mathrm{O}=1.6-6.6$ wt $\%$. In contrast, $\mathrm{Star}$ has $\mathrm{MgO}=9-33 \mathrm{wt} \%, \mathrm{SiO} 2=$ $23-46 \mathrm{wt} \%$ and $\mathrm{K}_{2} \mathrm{O}=1.8-5.6 \mathrm{wt} \%$. For a given $\mathrm{MgO}$ content, the Swartruggens kimberlite is slightly richer in $\mathrm{SiO}_{2}$ and $\mathrm{TiO}_{2}$ (Fig. 2). Trace element abundances are equally variable with the Swartruggens kimberlite having $\mathrm{La}=57-300 \mathrm{ppm}, \mathrm{Zr}=142-668 \mathrm{ppm}$ and $\mathrm{Nb}=54-227 \mathrm{ppm}$, whereas the Star kimberlite dykes show slightly less incompatible element variation, e.g. 119 - $285 \mathrm{ppm} \mathrm{La}, 31-410 \mathrm{ppm} \mathrm{Zr}$ and 68 - 200 ppm Nb. Compatible element abundances are also variable with Swartruggens kimberlite having 
$\mathrm{Ni}=61-1471 \mathrm{ppm}, \mathrm{Cr}=620-2088 \mathrm{ppm}$, and $\mathrm{Star} \mathrm{Ni}=$ $684-1710 \mathrm{ppm}$ and $\mathrm{Cr}=1800-2600 \mathrm{ppm}$. In contrast incompatible trace element ratios are more restricted and are similar between the two dykes swarms (Swartruggens: $\mathrm{Zr} / \mathrm{Hf}=47 \pm 4, \mathrm{La} / \mathrm{Th}=8 \pm 1, \mathrm{Ce} / \mathrm{Pb}=$ $12 \pm 5, \mathrm{~K} / \mathrm{Rb}=166 \pm 55 ; \mathrm{Star} \mathrm{Zr} / \mathrm{Hf}=41 \pm 5, \mathrm{La} / \mathrm{Th}=$ $7 \pm 1, \mathrm{Ce} / \mathrm{Pb}=16 \pm 1, \mathrm{~K} / \mathrm{Rb}=195 \pm 15$; e.g. Fig. 3 ).
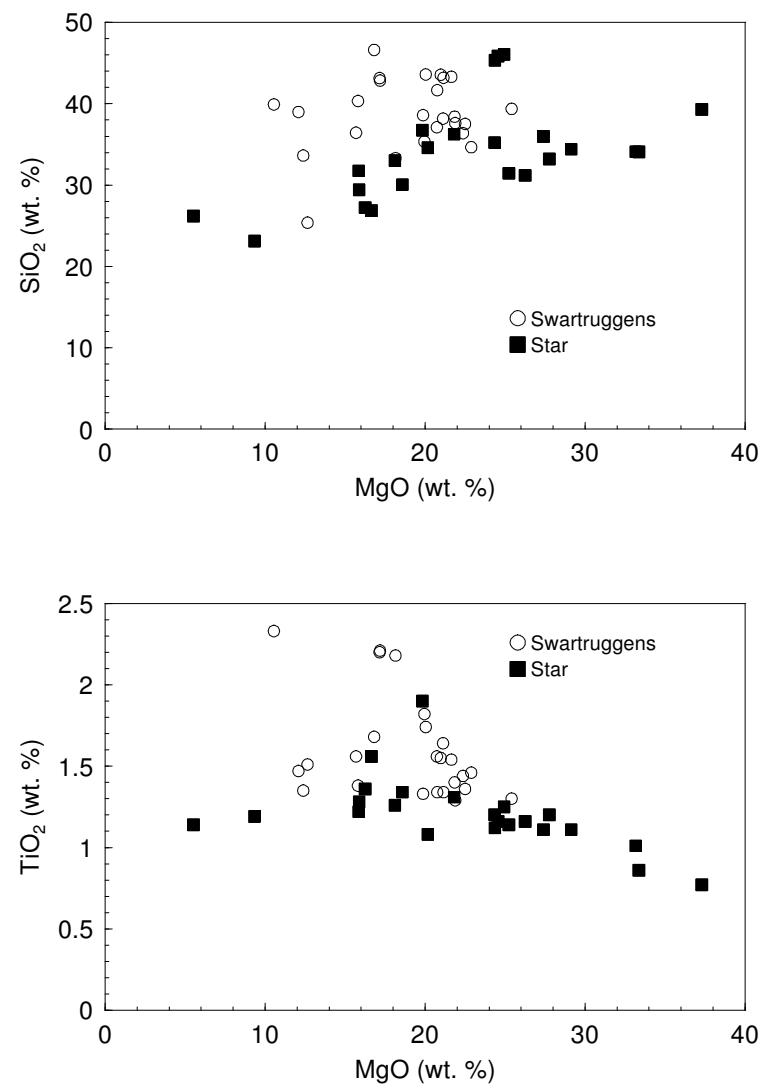

Figure 2: Selected major element variations within the Swartruggens and Star kimberlite dykes.

Chondrite normalised rare earth element patterns define steep, sub-parallel arrays, which are strongly enriched in the light rare earth elements (LREE) relative to heavy rare earth elements (HREE), with average $\mathrm{La} / \mathrm{Yb}_{\mathrm{n}}$ of 97 for the Swartruggens kimberlite and 205 for the Star kimberlite dykes. Normalised heavy REE abundances are 3-15 times chondrite for the Swartruggens kimberlite and 2 - 6 times chondrite for the Star kimberlite.

Primitive mantle normalised incompatible trace element patterns show strong negative $\mathrm{Ti}$ and $\mathrm{Sr}$ abundance anomalies, subdued negative $\mathrm{K}, \mathrm{Rb}, \mathrm{Nb}$ and $\mathrm{Ta}$ and positive $\mathrm{Pb}$ anomalies for both localities (Fig. 4). In addition, the Star kimberlite has slight negative $\mathrm{Zr}$ and $\mathrm{Hf}$ anomalies. The Muil dyke at Swartruggens is
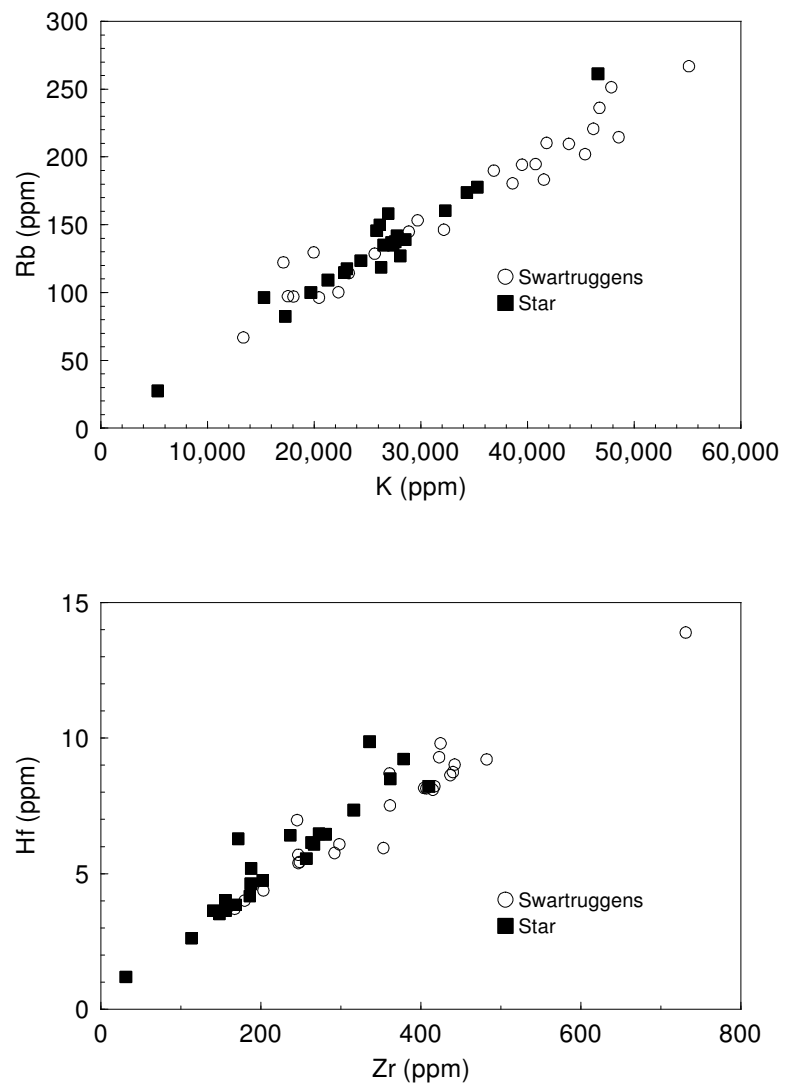

Figure 3: Incompatible trace element variations within the Swartruggens and Star kimberlite dykes; $\mathrm{Rb}$ versus $\mathrm{K}$ and $\mathrm{Hf}$ versus $\mathrm{Zr}$.

considerably less enriched than any of the other dykes and shows no Ti anomaly (Fig. 4).

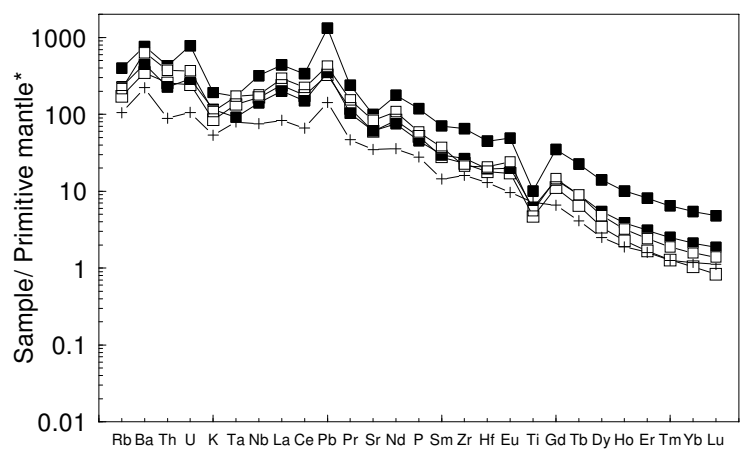

Figure 4: Primitive mantle normalized incompatible trace element diagram showing selected representative samples from Swartruggens and Star. Solid squares = Swartruggens, open squares $=$ Star, crosses $=$ Muil dyke. Primitive mantle normalizing values taken from Sun and McDonough (1989).

$\mathrm{Ni}$ variations indicate that there is no simple genetic relationship between the individual dykes at either locality, although intra-dyke variability is broadly consistent with olivine plus phlogopite control, inferred 
to occur through flow differentiation processes. This relationship is best developed in the Muil Dyke (Swartruggens).

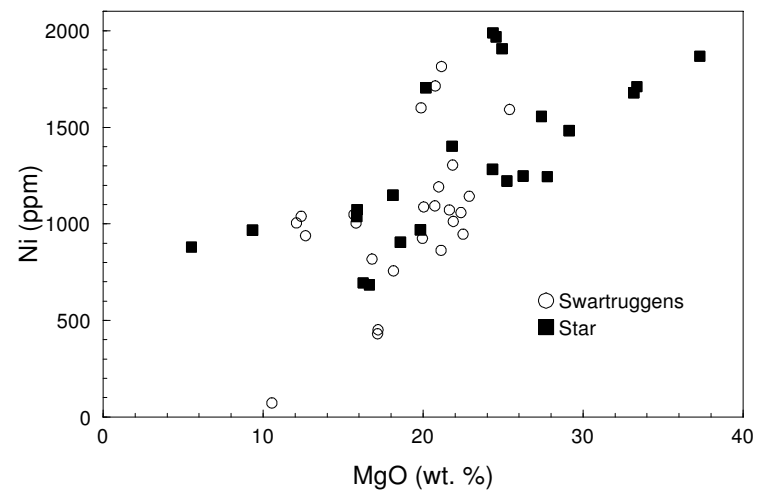

Figure 5: $\mathrm{Ni}$ versus $\mathrm{MgO}$ for the Swartruggens and Star kimberlites

Integration of major and trace element data together with petrography allow the nature of the likely source region of the primary kimberlite magmas to be inferred. Assuming low degrees of partial melting (e.g. Dalton and Presnall, 1998) the source regions to both these two Group II kimberlites were strongly enriched in incompatible trace elements, and, importantly, depleted in HREE relative to chondritic or primitive mantle values. This latter observation suggests that the respective source region of the Star and Swartruggens kimberlites were located within the lithospheric mantle, rather than within a convecting asthenospheric or plume mantle, and both sources had experienced a melt depletion event prior to strong metasomatic enrichment preceding kimberlite genesis (e.g. Tainton and McKenzie 1994).

\section{REFERENCES}

Birch, G.F., 1981. The karbonat-bombe; a precise, rapid and cheap instrument to determine calcium carbonate in sediments and rocks. Transactions of the Geological Society of South Africa 84(3). 199-203.

Dalton, J.A., Presnall, D.C., 1998. The Continuum of Primary Carbonatitic - Kimberlitic melt compositions in equilibrium with lherzolite: Data from the system $\mathrm{CaO}-\mathrm{MgO}-\mathrm{Al}_{2} \mathrm{O}_{3}-\mathrm{SiO}_{2}-\mathrm{CO}_{2}$ at $6 \mathrm{Gpa}$. Journal of Petrology 39(11-12). 1953-1964.

le Roex, A.P., Erlank, A.J., and Needham, H.D., 1981. Geochemical and mineralogical evidence for the occurrence of at least three distinct magma types in the 'Famous' region. Contributions to Mineralogy and Petrology 77. 24-37.

le Roex, A.P., Späth A., and Zartman R.E., 2001. Lithospheric thickness beneath the southern Kenya Rift: implications from basalt geochemistry. Contributions to Mineralogy and Petrology 142, 86106.

Skinner, E.M.W., Scott, B.H., 1979. Petrography, mineralogy and geochemistry of kimberlite and associated lamprophyre dykes near Swartruggens, Western Transvaal, R.S.A. Extended Abstracts, Second International Kimberlite Symposium, Cambridge, U.K., July 1979.

Tainton, K.M., McKenzie, D., 1994. The generation of kimberlites, lamproites, and their source rocks. Journal of Petrology 35(3). 787-817.

Contact: N Coe, Department of Geological Sciences,

University of Cape Town, Rondebosch 7701, South Africa,

E-mail: ncoe@geology.uct.ac.za 